\title{
A Comparative Study Of Water Quality Index (Wqi) Of Vagamon And Peermade Sub-Watersheds Of Meenachil And Pamba River Basins Of Western Ghats, Kerala, South India.
}

\author{
E. K. Manju 1, A. V. George 2 and V. B. Rekha 3 \\ I School of Environmental Science, Mahatma Gandhi University, Kottayam, Kerala, India. \\ 2 Vice-Chancellor, Mahatma Gandhi University, Kottayam, Kerala, India. \\ 3 Department of Environmental Science, Central University of Kerala, Vidhyanagar. PO, Kasargode.
}

\begin{abstract}
Water quality rating methods provide a single number that reflects the combined influence of different water quality parameters and is of much significance in the sustainable development of a watershed. $p H, E C, T D S$, total alkalinity, total hardness, chloride, nitrate and sulphate were used to calculate WQI in weighted arithmetic index method. Accordingly water quality is classified as excellent, good, poor, very poor and unfit for drinking. Thematic maps for the study area were prepared from SOI toposheets and IRS P6 LISSIII image (P100/R67) using Arc GIS 9.2 software. Spatial distribution maps were prepared for both watersheds by adding WQI index values as attribute data. In both sub-watersheds, percentage of excellent category is higher during Post monsoon season compared to other two seasons. When both sub-watersheds are compared Vagamon has better water quality than Peermade sub-watershed. It is represented by $44.44 \%$ excellent, $44.44 \%$ good and $11.12 \%$ poor category of WQI during Pre monsoon season; $33.33 \%$ excellent and $66.67 \%$ good category of WQI during Monsoon season; and $77.78 \%$ excellent and $22.22 \%$ good category WQI during Post monsoon season. The corresponding values for Peermade sub-watershed, for different seasons are $36.36 \%$ excellent and good, $18.18 \%$ poor and $9.10 \%$ very poor WQI during Pre monsoon; $36.36 \%$ excellent, $54.55 \%$ good and 9.09\% poor WQI during Monsoon; and 45.45\% excellent and good and $9.10 \%$ very poor category WQI during Post monsoon season.
\end{abstract}

Keywords: GIS, Peermade, Spatial distribution map, Vagamon, WQI.

\section{INTRODUCTION}

Watersheds are significant to every region as it provides drinking water, water for irrigation, recreation and industrial activities [1]. Growing population and speedy industrialization have lead to the pressure on demand for water [2] and affect the availability and quality of ground water. A continuous periodical monitoring of water quality is necessary for water resource management practices. Inadequate management of water resources, directly or indirectly, resulted in the degradation of hydrological environment [3]. The quality of groundwater vary with the depth of water table, seasonal changes and composition of dissolved salts depending upon sources of the salt and sub surface environment.

\section{Study Area}

Vagamon sub-watershed of Meenachil River and Peermade sub-watershed of Pamba River are the selected study areas for the present investigation. Both of them represents a typical highland sub-watershed having an altitude above $620 \mathrm{~m}$ and $1000 \mathrm{~m}$ of MSL respectively. Vagamon sub-watershed lies between $9^{\circ} 38^{\prime} 35^{\prime \prime}$ $\mathrm{N}$ to $9^{\circ} 41^{\prime} 42^{\prime \prime} \mathrm{N}$ latitude and $76^{\circ} 53^{\prime} 09^{\prime \prime} \mathrm{E}$ to $76^{\circ} 55^{\prime} 37^{\prime \prime} \mathrm{E}$ longitude and covers an area of $8.71 \mathrm{~km}^{2}$. Peermade sub-watershed lies between $76^{\circ} 56^{\prime} 01^{\prime \prime} \mathrm{E}$ to $76^{\circ} 59^{\prime} 57^{\prime \prime} \mathrm{E}$ longitude and $9^{\circ} 34^{\prime} 08^{\prime \prime} \mathrm{N}$ to $9^{\circ} 36^{\prime} 59^{\prime \prime} \mathrm{N}$ latitude and covers an area of $16.42 \mathrm{~km}^{2}$.

\section{Methodology}

The integrated status of various water quality parameters that are relevant and significant to particular use is reflected in WQI. Water quality index provides a single number (like a grade) that expresses overall water quality at certain location and time. It is one of the most effective ways to communicate the information on water quality trends to the general public or to the policy makers and water quality management [4].

WQI is calculated by weighed arithmetic index method [5].

$$
W Q I=\sum_{n=1}^{n} q_{n} w_{n} / \sum_{n=1}^{n} w_{n}
$$

$\mathrm{q}_{\mathrm{n}}=$ quality rating of $\mathrm{n}^{\text {th }}$ water quality parameter

$\mathrm{w}_{\mathrm{n}}=$ unit weight for $\mathrm{n}^{\text {th }}$ parameter 
Quality rating/sub index $\left(\mathrm{q}_{\mathrm{n}}\right)$ is a number reflecting the relative value of a parameter in the polluted water with respect to its standard permissible value.

Where $v_{n}=$ estimated value of the $\mathrm{n}^{\text {th }}$ parameter

$$
q_{n}=100\left[\left(v_{n}-v_{i o}\right) \div\left(s_{n}-v_{i o}\right)\right]
$$

$v_{i o}=$ ideal value of the $\mathrm{n}^{\text {th }}$ parameter

$s_{n}=$ standard permissible value of the $\mathrm{n}^{\text {th }}$ parameter

In most cases $v_{i o}=0$ except for parameters $\mathrm{pH}$ and DO.

For $\quad \mathrm{pH}, v_{i o}=7$ and $s_{n}=8.5$

DO, $v_{i o}=14.6$ and $s_{n}=5 \mathrm{mg} / \mathrm{L}$

Unit weight $\left(\mathrm{w}_{\mathrm{n}}\right)$ is inversely proportional to the recommended standards for the corresponding parameters $w_{n}=K / s_{n}$ where $K$ is a constant for proportionality $K=\frac{1}{\sum^{1} / s_{n}}$

Table 1. Status of Water Quality based on WQI [6]

\begin{tabular}{cc}
\hline Water Quality Index & Status \\
\hline $0-25$ & Excellent \\
$26-50$ & Good \\
$51-75$ & Poor \\
$76-100$ & Very Poor \\
100 and above & Unfit for drinking (UFD) \\
\hline
\end{tabular}

Table 2. Calculation of Unit weight for parameters

\begin{tabular}{cccc}
\hline & $\boldsymbol{s}_{\boldsymbol{n}}$ & $\mathbf{1} / \boldsymbol{s}_{\boldsymbol{n}}$ & $\mathrm{w}=\mathrm{k} / \boldsymbol{s}_{\boldsymbol{n}}$ \\
\hline $\mathbf{p H}$ & 9 & 0.118 & 0.702 \\
EC & 300 & 0.003 & 0.020 \\
TDS & 500 & 0.002 & 0.012 \\
Alkalinity & 120 & 0.008 & 0.050 \\
Chloride & 250 & 0.004 & 0.024 \\
Hardness & 200 & 0.005 & 0.030 \\
Nitrate & 45 & 0.022 & 0.133 \\
Sulphate & 200 & 0.005 & 0.030 \\
\hline & $\sum \mathbf{1} / \boldsymbol{s}_{\boldsymbol{n}}$ & $\mathbf{0 . 1 6 8}$ & \\
\hline
\end{tabular}

Water quality is classified as excellent, good, poor, very poor and unfit for drinking and its status is presented in Table 1. The most important factor in determining the WQI is the selection of water quality parameters. Influence of water quality parameters on status of pollution depends on the permissible levels suggested by BIS. Parameters having low permissible limits are more harmful to the quality of water because a slight increases affects the value great extent. Since selection of too many parameters might widen the water quality index, and the significance of various parameters depends on the intended use of water, in the present investigation, eight Physico-chemical parameters viz. pH, EC, TDS, Total alkalinity, total hardness, chloride, nitrate and sulphate were used to calculate WQI. Unit weight for the parameters is calculated in Table 2. Various physico-chemical parameters were analysed during every month and water quality index was calculated.

Thematic maps for the study area were prepared from SOI toposheets and IRS P6 LISS-III image (P100/R67) using Arc GIS 9.2 software.WQI index values were added as attribute data and spatial distribution maps for both sub-watersheds were prepared.

\section{Result And Discussion}

The variations in WQI during Pre monsoon, Monsoon and Post monsoon seasons for Vagamon subwatershed is presented in Table 3. and Fig. 1. During the Pre monsoon period WQI varies between 4.44 (V8) and 57.81 (V3). During Monsoon the variations are from 2.96 (V3) to 44.36 (V9) and in Post monsoon, corresponding changes in WQI values are from 4.54 (V5) to 38.22 (V9). The mean value of WQI for the entire Vagamon sub-watershed is also presented in the table 2. The highest mean value of WQI, was reported from the sample station V9 (38.96) and lowest from sample station V8 (4.61). During Pre monsoon, the sampling stations V1, V4, V7 and V8 are under excellent category, V2, V5, V6 and V9 are in the good category and V3 is in the 
poor category of WQI classification status. During Monsoon season, stations V3, V6 and V8 are under excellent category and stations V1, V2, V4, V5, V7 and V9 under good category. During Post monsoon season sampling stations V1, V2, V3, V4, V5, V7 and V8 are under excellent category and stations V6 and V9 under good category. Variations in WQI values for different seasons in Vagamon sub-watershed is represented as GIS spatial diagrams in Fig. 2., Fig. 3., and Fig. 4. which also agree very well with the above made observations.

Table 3. WQI of Vagamon Sub-Watershed

\begin{tabular}{|c|c|c|c|c|c|}
\hline \multirow[t]{2}{*}{$\mathbf{N}$} & \multirow[t]{2}{*}{$\mathbf{S}$} & \multicolumn{4}{|c|}{ Water Quality Index } \\
\hline & & 1 & 2 & 3 & Mean \\
\hline \multirow{9}{*}{ 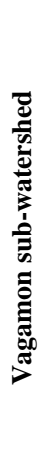 } & V1 & 7.47 & 26.06 & 7.25 & 13.59 \\
\hline & V2 & 38.53 & 29.04 & 22.89 & 30.15 \\
\hline & V3 & 57.81 & 2.96 & 8.13 & 22.97 \\
\hline & V4 & 16.35 & 39.59 & 13.13 & 23.02 \\
\hline & V5 & 33.88 & 29.51 & 4.54 & 22.64 \\
\hline & V6 & 32.65 & 17.11 & 33.29 & 27.68 \\
\hline & V7 & 12.37 & 39.96 & 22.18 & 24.84 \\
\hline & V8 & 4.44 & 3.76 & 5.62 & 4.61 \\
\hline & V9 & 34.31 & 44.36 & 38.22 & 38.96 \\
\hline
\end{tabular}

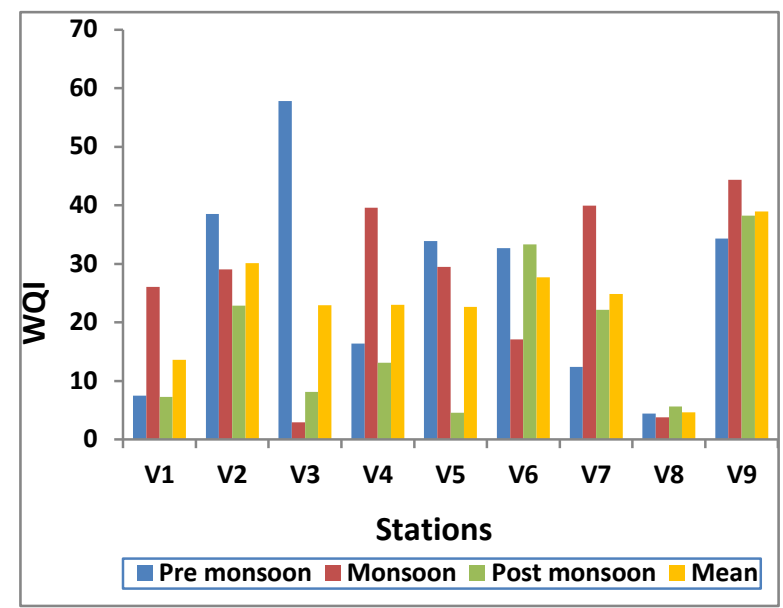

Fig. 1. Seasonal variations of WQI in Vagamon SubWatershed

According to the classification of WQI of Vagamon sub-watershed, during Pre monsoon season (Fig. 5.) $44.44 \%$ of sample stations are in excellent category, $44.44 \%$ are in good category and $11.11 \%$ are in poor category. During Monsoon season (Fig. 6.) $33.33 \%$ sample stations are in excellent category and $66.67 \%$ are in good category. During Post monsoon season (Fig. 7.) $77.78 \%$ sample stations are in excellent category and $22.22 \%$ are in good category.

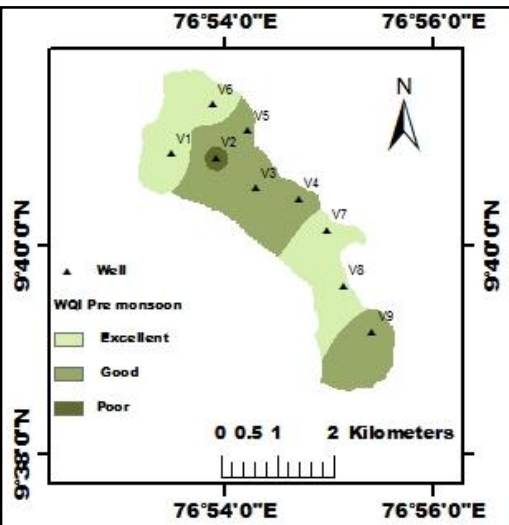

Fig.2. Variation of WQI in Vagamon Sub-Watershed during Pre monsoon season

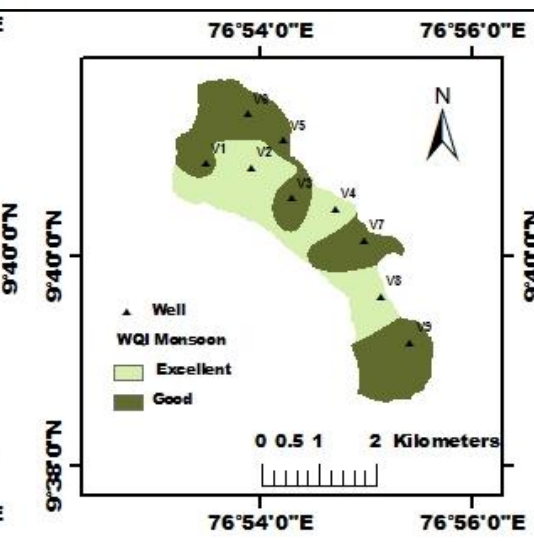

Fig. 3. Variation of WQI in Vagamon Sub-Watershed during monsoon season

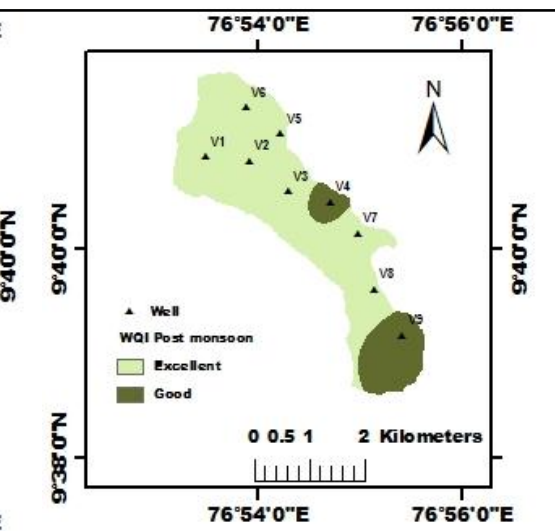

Fig. 4. Variation of WQI in Vagamon Sub-Watershed during Post monsoon season 


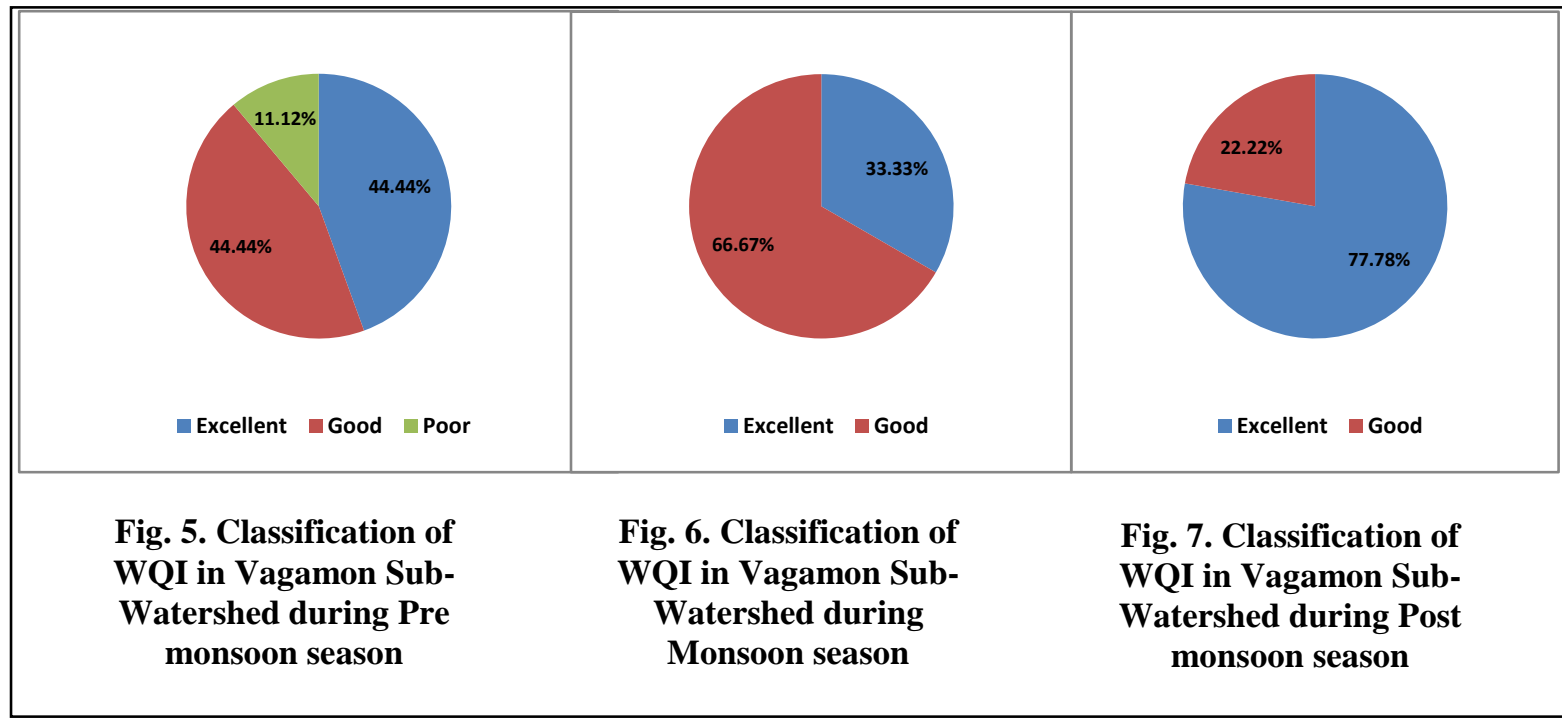

WQI during Pre monsoon, Monsoon and Post monsoon seasons for Peermade sub-watershed is represented in Table 4. The seasonal variation in mean value of WQI is presented in Fig. 8. During the Pre monsoon period WQI varies between 5.60 (P9) and 95.74 (P1). During Monsoon it varies from 6.86 (P6) to 67.33 (P1). During Post monsoon, corresponding changes in WQI values are 4.95 (P6) to 92.54 (P1). The mean value of WQI for the entire Peermade sub-watershed is also presented in the Table 3 . The highest mean value of WQI, 85.20 was reported from the sample station P1 and the lowest value of 14.23 from sample station P6.

During Pre monsoon, the sampling stations P8, P9, P10 and P11 are coming under the excellent category, P3, P4, P6 and P7 come under the good category and P2 and P5 is in the poor category and P1 comes under Very poor category of WQI classification status. During Monsoon season, stations P5, P6, P7 and P8 are under excellent category, stations P2, P3, P4, P9, P10 and P11 under good category and station P1 under poor category. During Post monsoon season sampling stations namely P3, P5, P6, P7 and P8 are under excellent category and stations $\mathrm{P} 2, \mathrm{P} 4, \mathrm{P} 9, \mathrm{P} 10$ and $\mathrm{P} 11$ are under good category and station $\mathrm{P} 1$ comes under very poor category. Variations in the WQI values for different seasons of Peermade sub-watershed is also represented as GIS spatial diagrams in Fig. 9, Fig. 10 and Fig. 11. which also agree with the above made observations.

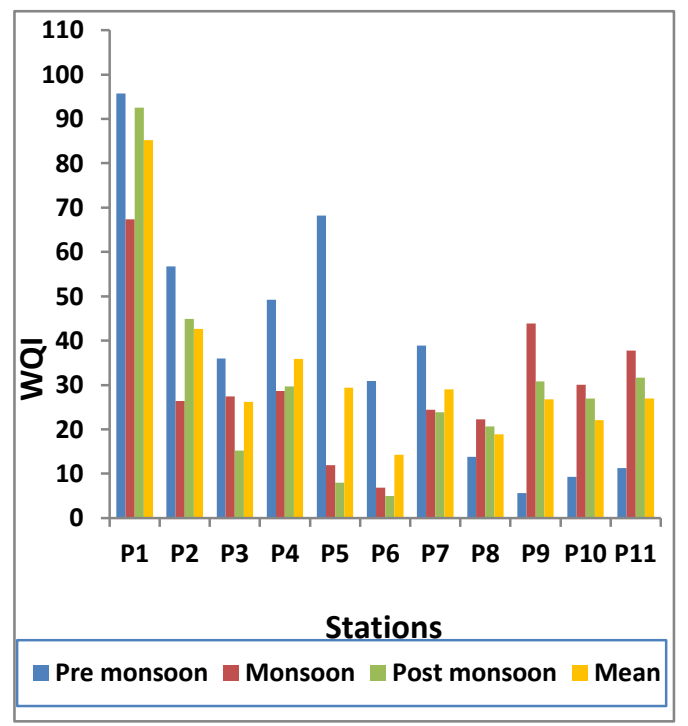

Fig. 8. Seasonal variations of WQI in Peermade Sub- watershed
Table 4. WQI of Peermade Sub-Watershed

\begin{tabular}{|c|c|c|c|c|c|}
\hline \multirow{2}{*}{$\mathrm{N}$} & \multirow{2}{*}{ S } & \multicolumn{4}{|c|}{ Water Quality Index } \\
\hline & & $\begin{array}{c}1 \\
\text { monso }\end{array}$ & 2 & $\begin{array}{c}3 \\
\text { monso }\end{array}$ & Mean \\
\hline \multirow{11}{*}{ 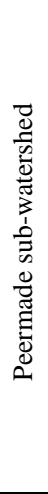 } & $\mathrm{P} 1$ & 95.74 & 67.33 & 92.54 & 85.20 \\
\hline & P2 & 56.75 & 26.36 & 44.94 & 42.68 \\
\hline & P3 & 35.97 & 27.43 & 15.20 & 26.20 \\
\hline & $\mathrm{P} 4$ & 49.24 & 28.69 & 29.67 & 35.87 \\
\hline & P5 & 68.25 & 11.95 & 8.02 & 29.41 \\
\hline & P6 & 30.88 & 6.86 & 4.95 & 14.23 \\
\hline & P7 & 38.85 & 24.46 & 23.82 & 29.04 \\
\hline & P8 & 13.78 & 22.22 & 20.65 & 18.88 \\
\hline & P9 & 5.60 & 43.88 & 30.81 & 26.76 \\
\hline & P10 & 9.29 & 30.09 & 26.93 & 22.10 \\
\hline & P11 & 11.31 & 37.77 & 31.65 & 26.91 \\
\hline & & 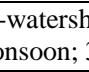 & $\mathrm{S}=\mathrm{St}$ & ID & Pre \\
\hline
\end{tabular}


In Peermade sub-watershed, during Pre monsoon season (Fig. 12) $36.36 \%$ of the sample stations are in excellent and good category, $18.18 \%$ are in poor category and $9.09 \%$ are in very poor category. During Monsoon season (Fig. 13) 36.36\% are in excellent category, 54.55\% are in good category and 9.09\% are in poor category. During Post monsoon season (Fig. 14) $45.45 \%$ stations are in excellent and good category and $9.09 \%$ are in very poor category.
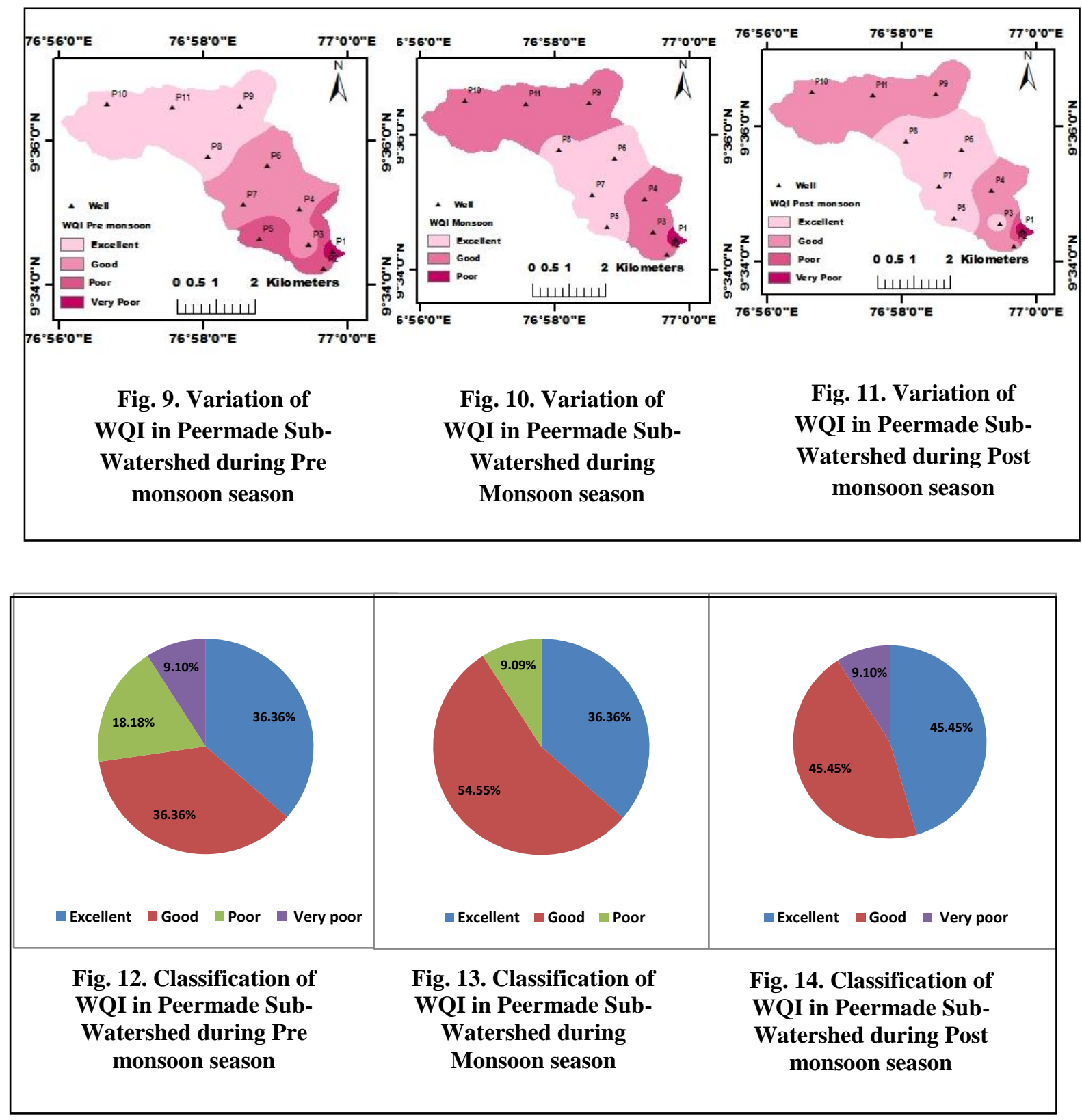

\section{Conclusion}

The present investigation reveals the seasonal variations in water quality Index of Vagamon and Peermade sub-watersheds. The results show that in both the sub-watersheds, percentage of excellent category is higher during Post monsoon season compared to the other two seasons. In comparison with Peermade subwatershed, Vagamon sub-watershed has the maximum excellent category i.e., 77.78\% during Post monsoon season. A comparative analysis shows that in general Vagamon sub-watershed has good water quality than Peermade. Vagamon sub-watershed has $44.44 \%$ excellent, $44.44 \%$ good and $11.12 \%$ poor category WQI during Pre monsoon season; $33.33 \%$ excellent and $66.67 \%$ good category WQI during Monsoon; and $77.78 \%$ excellent and $22.22 \%$ good category WQI during Post monsoon season. Peermade sub-watershed on the other hand is represented by $36.36 \%$ excellent and good category, and $18.18 \%$ poor category and $9.10 \%$ very poor category WQI during Pre monsoon season, 36.36\% excellent, 54.55\% good and 9.09\% poor category WQI during Monsoon and $45.45 \%$ excellent and good and $9.10 \%$ very poor category WQI during Post monsoon season. 
Vagamon sub-watershed has only excellent and good WQI during Monsoon and Post monsoon seasons and has only very little amount of poor i.e., 11.12\% WQI during Pre monsoon season. But in the case of Peermade subwatershed poor and very poor category is present in all the seasons i.e., 9.10\% very poor during Pre monsoon and Post monsoon seasons and $18.18 \%$ and $9.09 \%$ poor, during Pre monsoon and Monsoon seasons respectively. Thus from the present investigation it can be reasonably concluded that Monsoon recharge is playing an important role in keeping the quality of water in good condition in both Vagamon and Peermade subwatersheds.

\section{Acknowledgement}

The authors gratefully acknowledge the Director, School of Environmental Science, M.G. University, Kottayam for the support extended and facilities provided during the course of study.

\section{Reference}

[1] V.B. Rekha, A.V.George, and M. Rita, A comparative study of water quality index (WQI) of Peruvanthanam and Valiyathodu subwatersheds of Manimala river basin, Kerala.South India. IOSR Journal of Environmental Science,Toxicology and Food Technology (IOSR-JESTFT), 3(4), 2013, 01-06.

[2] S. Ananthakrishnan, K. Loganathan, and A. Jafar ahamed, Study on ground water quality and its suitability or drinking purpose in Alathur block -Perambalur district, Archives of Applied Science Research, 4(3), 2012, 1332-1338.

[3] K.R.Karnath, Hydrogoology (Tata Mc.Graw Hill publishing company Ltd., New Delhi, 1989).

[4] Rashmi Sisodia, and Chaturbhuj Moundiotiya, Assessment of the Water Quality Index of Wetland Kalakho Lake, Rajasthan, India, Journal of Environmental Hydrology, 1(14), 2006, 23.

[5] R.M. Brown, N.J. Mc Cleiland, R.A. Deininger, and M.F. O’Connor, A water quality index - crossing the psychological barrier (Jenkis, S.H. ed.), Proc. Int. Conf. on Water Poll. Res., Jerusalem, 6, 1972, 787-797.

[6] P.C. Mishra, and R.K. Patel, Quality of Drinking water in Rourkela, outside the steel town ship, Journal of Environmental. Pollusion, 8(2), 2001, 165-169. 